\title{
A Raman and infrared spectroscopic study of the phosphate mineral laueite
}

\author{
Ray L. Frost ${ }^{\mathrm{a}, *}$, Ricardo Scholz ${ }^{\mathrm{b}}$, Andrés López ${ }^{\mathrm{a}}$ \\ a School of Chemistry, Physics and Mechanical Engineering, Science and Engineering Faculty, Queensland University of Technology, GPO Box 2434, Brisbane, \\ Queensland 4001, Australia \\ b Geology Department, School of Mines, Federal University of Ouro Preto, Campus Morro do Cruzeiro, Ouro Preto, MG 35, 400-00, Brazil
}

\section{A R T I C L E I N F O}

\section{Article history:}

Received 24 February 2015

Received in revised form 1 December 2015

Accepted 1 December 2015

Available online 2 December 2015

\section{Keywords:}

Laueite

Phosphate

Hydroxyl

Raman spectroscopy

Infrared spectroscopy

\begin{abstract}
A B S T R A C T
A laueite mineral sample from Lavra Da Ilha, Minas Gerais, Brazil has been studied by vibrational spectroscopy and scanning electron microscopy with EDX. Chemical formula calculated on the basis of semi-quantitative chemical analysis can be expressed as $\left(\mathrm{Mn}^{2+}{ }_{0.85}, \mathrm{Fe}^{2+}{ }_{0.10} \mathrm{Mg}_{0.05}\right)_{\sum 1.00}\left(\mathrm{Fe}^{3+}{ }_{1.90}, \mathrm{Al}_{0.10}\right)_{\sum 2.00}\left(\mathrm{PO}_{4}\right)_{2}(\mathrm{OH})_{2} \cdot 8 \mathrm{H}_{2} \mathrm{O}$.

The laueite structure is based on an infinite chains of vertex-linked oxygen octahedra, with $\mathrm{Fe}^{3+}$ occupying the octahedral centers, the chain oriented parallel to the $c$-axis and linked by $\mathrm{PO}_{4}$ groups. Consequentially not all phosphate units are identical. Two intense Raman bands observed at 980 and $1045 \mathrm{~cm}^{-1}$ are assigned to the $v_{1} \mathrm{PO}_{4}{ }^{3-}$ symmetric stretching mode. Intense Raman bands are observed at 525 and $551 \mathrm{~cm}^{-1}$ with a shoulder at $542 \mathrm{~cm}^{-1}$ are assigned to the $v_{4}$ out of plane bending modes of the $\mathrm{PO}_{4}{ }^{3-}$. The observation of multiple bands supports the concept of non-equivalent phosphate units in the structure. Intense Raman bands are observed at 3379 and $3478 \mathrm{~cm}^{-1}$ and are attributed to the $\mathrm{OH}$ stretching vibrations of the hydroxyl units. Intense broad infrared bands are observed. Vibrational spectroscopy enables subtle details of the molecular structure of laueite to be determined.
\end{abstract}

(c) 2015 Elsevier B.V. All rights reserved.

\section{Introduction}

The mineral laueite of formula $\mathrm{Mn}^{2+} \mathrm{Fe}_{2}{ }^{3+}\left(\mathrm{PO}_{4}\right)_{2}(\mathrm{OH})_{2} \cdot 8 \mathrm{H}_{2} \mathrm{O}$ $[1,2]$ is a hydrated hydroxy phosphate of ferric iron and manganese. The mineral is a member of the homonimous mineral group. Other minerals in this group are césarferreiraite $\mathrm{Fe}^{2+}\left(\mathrm{Fe}^{3+}\right)_{2}\left(\mathrm{AsO}_{4}\right)_{2}(\mathrm{OH})_{2} \cdot 8 \mathrm{H}_{2} \mathrm{O}$, ferrolaueite $\mathrm{Fe}^{2}$ ${ }^{+} \mathrm{Fe}_{2}{ }^{3+}\left(\mathrm{PO}_{4}\right)_{2}(\mathrm{OH})_{2} \cdot 8 \mathrm{H}_{2} \mathrm{O}$, gordonite $\mathrm{MgAl}_{2}{ }^{3+}\left(\mathrm{PO}_{4}\right)_{2}(\mathrm{OH})_{2} \cdot 8 \mathrm{H}_{2} \mathrm{O}$, kastningite $\left(\mathrm{Mn}^{2+}, \mathrm{Fe}^{2+}, \mathrm{Mg}\right) \mathrm{Al}_{2}\left(\mathrm{PO}_{4}\right)_{2}(\mathrm{OH})_{2} \cdot 8 \mathrm{H}_{2} \mathrm{O}$, laueite $\mathrm{Mn}^{2}$ ${ }^{+} \mathrm{Fe}_{2}{ }^{3+}\left(\mathrm{PO}_{4}\right)_{2}(\mathrm{OH})_{2} \cdot 8 \mathrm{H}_{2} \mathrm{O}$, maghrebite $\mathrm{MgAl}_{2}\left(\mathrm{AsO}_{4}\right)_{2}(\mathrm{OH})_{2} \cdot 8 \mathrm{H}_{2} \mathrm{O}$, mangangordonite $\mathrm{Mn}^{2+} \mathrm{Al}_{2}{ }^{3+}\left(\mathrm{PO}_{4}\right)_{2}(\mathrm{OH})_{2} \cdot 8 \mathrm{H}_{2} \mathrm{O}$, paravauxite $\mathrm{Fe}^{2}$ ${ }^{+} \mathrm{Al}_{2}{ }^{3+}\left(\mathrm{PO}_{4}\right)_{2}(\mathrm{OH})_{2} \cdot 8 \mathrm{H}_{2} \mathrm{O}$ [3], sigloite $\mathrm{Fe}^{3+} \mathrm{Al}_{2}{ }^{3+}\left(\mathrm{PO}_{4}\right)_{2}(\mathrm{OH})_{2} \cdot 7 \mathrm{H}_{2} \mathrm{O}$ [4] and ushkovite $\mathrm{MgFe}_{2}{ }^{3+}\left(\mathrm{PO}_{4}\right)_{2}(\mathrm{OH})_{2} \cdot 8 \mathrm{H}_{2} \mathrm{O}$ [5-8].

The mineral was named by Hugo Strunz in 1954 in honor of Max Felix Theodor von Laue (1879-1960). Laue was the first to verify that minerals had a regular atomic arrangement as had been predicted by previous physicists. Laueite was first described from Hagendorf South pegmatite, Bavaria, Germany. Laueite is dimorphous with the mineral gordonite [9]. Crystal structure of laueite

\footnotetext{
* Corresponding author. Fax: +61 731381804.

E-mail address: r.frost@qut.edu.au (R.L. Frost).
}

was determined by Moore [5-7]. Moore found that there were two isotypes and 3 polymorphs for laueite [5]. The laueite structure is based on an infinite chain of vertex-linked oxygen octahedra, with $\mathrm{Fe}^{3+}$ occupying the octahedral centers, the chains oriented parallel to the $c$-axis. The mineral shows triclinic symmetry, space group $P$ 1, and unit cell parameters are: $a=5.28 \AA, b=10.66 \AA, c=7.14 \AA$, $\alpha=107.91^{\circ}, \beta=110.98^{\circ}, \gamma=71.12^{\circ}$.

As paravauxite is isostructural with laueite $\mathrm{Mn}^{2+} \mathrm{Fe}^{3}$ ${ }_{2}^{+}\left(\mathrm{PO}_{4}\right)_{2}(\mathrm{OH})_{2} \cdot 8 \mathrm{H}_{2} \mathrm{O}[3,12]$, it could be indirectly concluded that the structure of paravauxite is based on an infinite chain of vertexlinked oxygen octahedra, with Al occupying the octahedral centers, the chain oriented parallel to the $c$-axis. Chains are in turn connected to others by $\mathrm{PO}_{4}$ tetrahedra which also bridge through isolated octahedra (with $\mathrm{Fe}^{2+}$ as centers). The laueite structural formula is $\mathrm{Mn}^{2+} \mathrm{Fe}^{3+}{ }_{2}(\mathrm{OH})_{2}\left(\mathrm{PO}_{4}\right)_{2}\left(\mathrm{H}_{2} \mathrm{O}\right)_{6} \cdot 2 \mathrm{H}_{2} \mathrm{O}$ [3], and according to analogy, the paravauxite structural formula is then $\mathrm{Fe}^{2+} \mathrm{Al}_{2}(\mathrm{OH})_{2}(-$ $\left.\mathrm{PO}^{4}\right)_{2}\left(\mathrm{H}_{2} \mathrm{O}\right)_{6} \cdot 2 \mathrm{H}_{2} \mathrm{O}$ and the non-octahedrally bonded waters appearing in a cavity left in the structure. In detailed description, in analogy with laueite structure [3], the chains of Al-octahedra decorated by flanking $\mathrm{PO}_{4}{ }^{3-}$ groups (which extend in c-direction) meld in the $a$-direction by sharing one quarter of the flanking $\mathrm{PO}_{4}$ vertices with octahedra of adjacent chains to form an $\left[\mathrm{Al}_{2}\left(\mathrm{PO}_{4}\right)_{2}(\mathrm{OH})_{2}\left(\mathrm{H}_{2} \mathrm{O}\right)_{2}\right]$ sheet. In the resulting sheet, the $\mathrm{PO}_{4}$ 
tetrahedra are three-connected. There are two distinct octahedra in these sheets, one of which is six-connected within the sheet, and the other of which is only four-connected and has $\left(\mathrm{H}_{2} \mathrm{O}\right)$ at two vertices.

Raman spectroscopy has proven very useful for the study of minerals, especially minerals containing oxyanions such as phosphate [3,4]. This paper is a part of systematic studies of vibrational spectra of minerals of secondary origin in the oxide supergene zone. The objective of this research is to report the Raman and infrared spectra of laueite and to relate the spectra to the molecular structure of the mineral.

\section{Experimental}

\subsection{Samples description and preparation}

The mineral laueite studied in this work was obtained from the collection of the Geology Department of the Federal University of Ouro Preto, Minas Gerais, Brazil, with sample code SAE-025. The laueite originated from the Cigana mine, Conselheiro Pena, Minas Gerais, Brazil. The mineral occurs in association with frondelite in a paragenesis related to the hydrothermal alteration of triphylite in Li-bearing pegmatites. Crystals of laueite can make nice specimens with their colorless or light green color and glassy luster. The mineral is an uncommon species in complex zoned pegmatites.

The sample was gently crushed and the associated minerals were removed under a stereomicroscope Leica MZ4. Scanning electron microscopy (SEM) was applied to support the mineral chemistry.

\subsection{Scanning electron microscopy (SEM)}

Experiments and analyses involving electron microscopy were performed in the NanoLab, REDEMAT, School of Mines, Universidade Federal de Ouro Preto, Ouro Preto, Minas Gerais, Brazil. Laueite crystals were coated with a $5 \mathrm{~nm}$ layer of evaporated carbon. Secondary electron image was obtained using a TESCAN VEGA 3 equipment. Qualitative and semi-quantitative chemical analyses in the EDS mode were performed with an Oxford spectrometer and were applied to support the mineral characterization.

\section{Raman spectroscopy}

Crystals of laueite were placed on a polished metal surface on the stage of an Olympus BHSM microscope, which is equipped with $10 \times, 20 \times$, and $50 \times$ objectives. The microscope is part of a Renishaw 1000 Raman microscope system, which also includes a monochromator, a filter system and a CCD detector (1024 pixels). The Raman spectra were excited by a Spectra-Physics model 127 He-Ne laser producing highly polarised light at $633 \mathrm{~nm}$ and collected at a nominal resolution of $2 \mathrm{~cm}^{-1}$ and a precision of $\pm 1 \mathrm{~cm}^{-1}$ in the range between 4000 and $100 \mathrm{~cm}^{-1}$. Some of these phosphate minerals fluoresced badly at $633 \mathrm{~nm}$; as a consequence other laser excitation wavelengths were used especially the $785 \mathrm{~nm}$ laser. The power at the sample was $0.1 \mathrm{~mW}$.

Repeated acquisitions on the crystals using the highest magnification $(50 \times)$ were accumulated to improve the signal to noise ratio of the spectra. Spectra were calibrated using the $520.5 \mathrm{~cm}^{-1}$ line of a silicon wafer. Previous studies by the authors provide more details of the experimental technique. Alignment of all crystals in a similar orientation has been attempted and achieved. However, differences in intensity may be observed due to minor differences in the crystal orientation.
A Raman spectrum of laueite is provided in the RRUFF data base. The spectrum only covers the $1200-100 \mathrm{~cm}^{-1}$ spectral range. This spectrum is provided in Supplementary information as Fig. S1.

\section{Infrared spectroscopy}

Infrared spectra were obtained using a Nicolet Nexus 870 FTIR spectrometer with a smart endurance single bounce diamond ATR cell. Spectra over the $4000-600 \mathrm{~cm}^{-1}$ range were obtained by the co-addition of 128 scans with a resolution of $4 \mathrm{~cm}^{-1}$ and a mirror velocity of $0.6329 \mathrm{~cm} / \mathrm{s}$. Spectra were co-added to improve the signal to noise ratio.

Spectral manipulation such as baseline correction/adjustment and smoothing were performed using the Spectracalc software package GRAMS (Galactic Industries Corporation, NH, USA). Band component analysis was undertaken using the Jandel 'Peakfit' software package that enabled the type of fitting function to be selected and allows specific parameters to be fixed or varied accordingly. Band fitting was done using a Lorentzian-Gaussian cross-product function with the minimum number of component bands used for the fitting process. The Gaussian-Lorentzian ratio was maintained at values greater than 0.7 and fitting was undertaken until reproducible results were obtained with squared correlations of $r^{2}$ greater than 0.995 .

\section{Results and discussion}

\subsection{Chemical characterization}

The BSI image of laueite sample studied in this work is shown in Fig. 1. Qualitative and semi-quantitative chemical composition shows a Fe and Mn phosphate phase with minor amounts of $\mathrm{Mg}$ and $\mathrm{Al}$. The chemical analysis is represented as an EDX spectrum in Fig. 2. On the basis of semiquantitative chemical analyses the

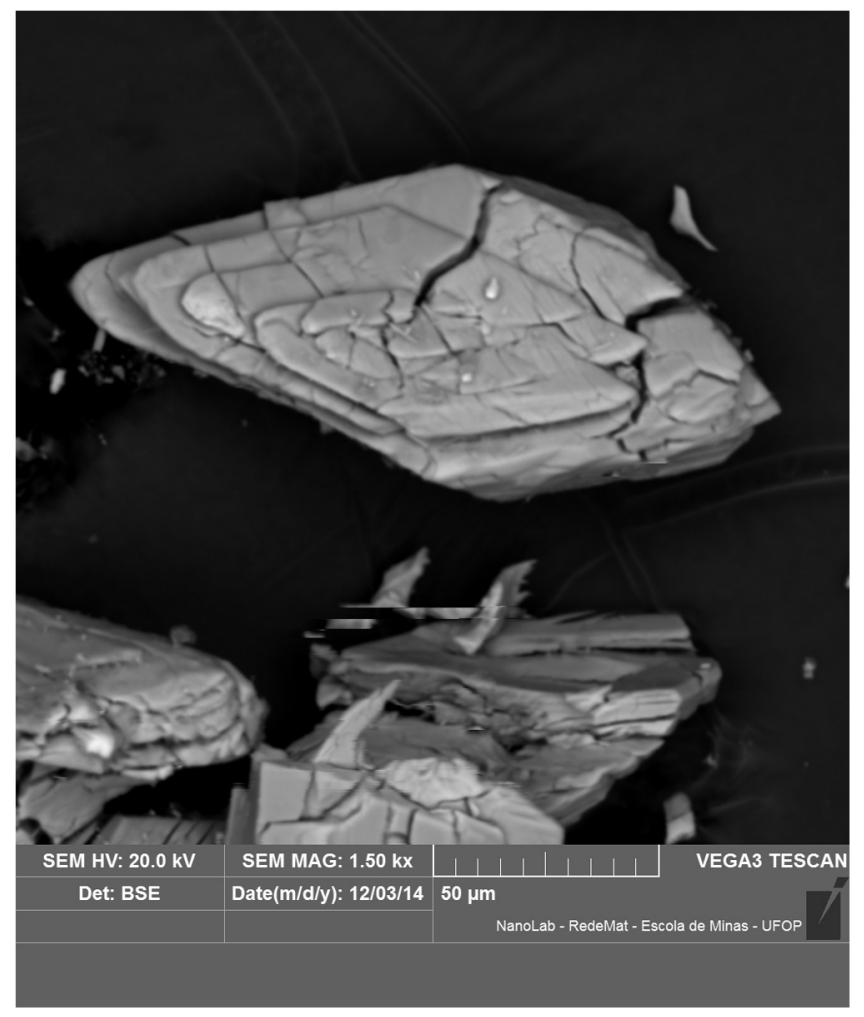

Fig. 1. SEM image of Brazilian laueite. 


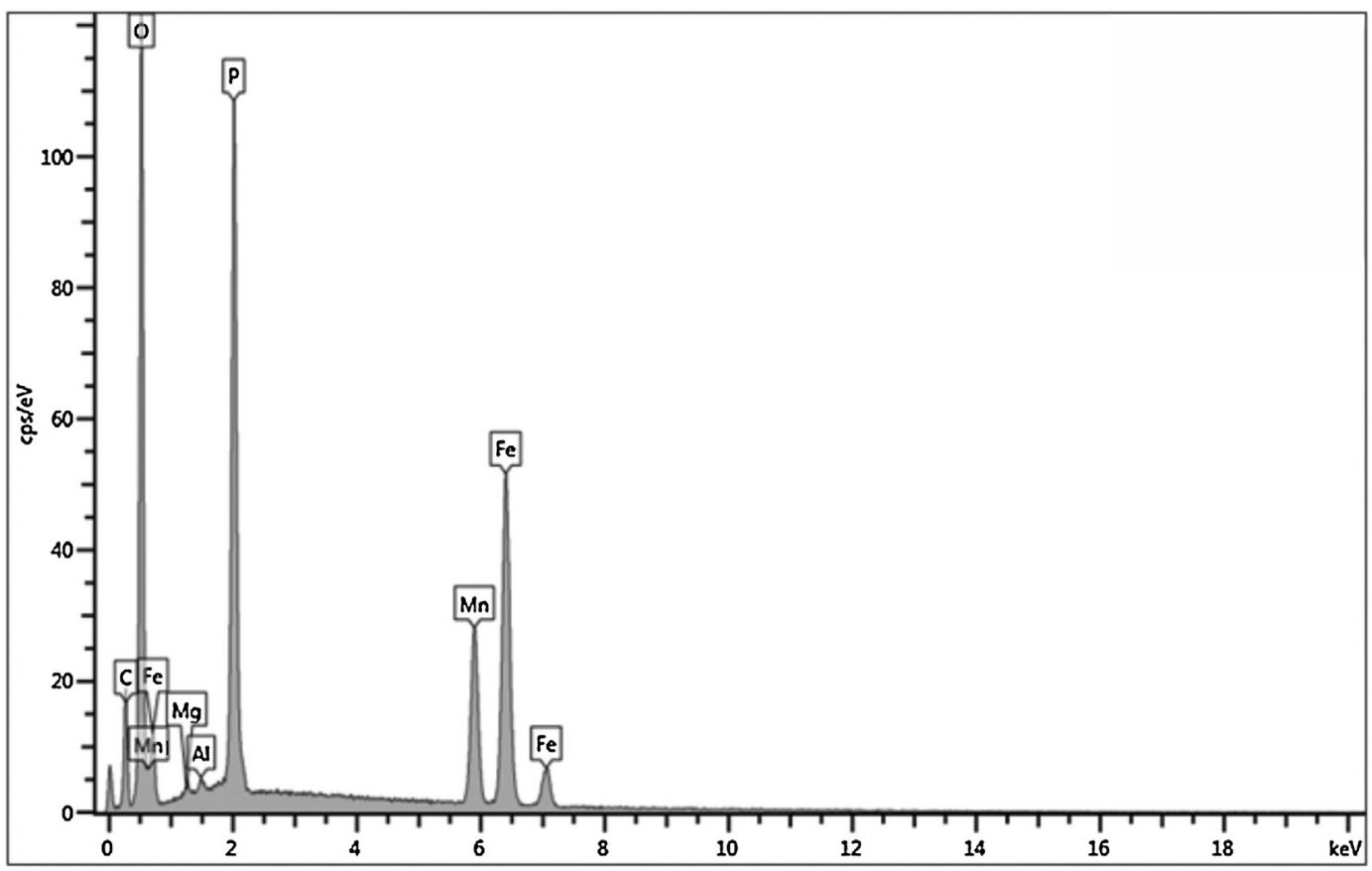

Fig. 2. EDX analysis of Brazilian laueite.

chemical formula was calculated and can be expressed as $\left(\mathrm{Mn}^{2}\right.$ $\left.{ }_{0.85}^{+}, \mathrm{Fe}^{2+}{ }_{0.10} \mathrm{Mg}_{0.05}\right)_{\sum 1.00}\left(\mathrm{Fe}^{3+}{ }_{1.90} \mathrm{Al}_{0.10}\right)_{\sum 2.00}\left(\mathrm{PO}_{4}\right)_{2}(\mathrm{OH})_{2} \cdot 8 \mathrm{H}_{2} \mathrm{O}$.

\section{Vibrational spectroscopy}

The Raman spectrum of laueite over the $4000-100 \mathrm{~cm}^{-1}$ spectral range is reported in Fig. 3a. This spectrum was obtained using the $633 \mathrm{~nm}$ laser. The spectrum shows complexity with many bands being observed. This figure shows the position and relative intensities of the Raman bands. It is noteworthy that there are large parts of the spectrum where no intensity is observed. The Raman spectrum is therefore, subdivided into sections depending upon the type of vibration being analysed. The infrared spectrum of laueite over the $4000-600 \mathrm{~cm}^{-1}$ spectral range is displayed in Fig. $3 \mathrm{~b}$. The spectrum is not shown below $600 \mathrm{~cm}^{-1}$. The reason for this is that we are using a reflection technique and the ATR cell absorbs all incident radiation below this wavenumber. There are parts of this infrared spectrum where little or no intensity is observed. This spectrum may be thus subdivided into sections depending upon the type of vibration being analyzed. A summary of the spectroscopic data is given in Table 1 .

The Raman spectrum of the laueite mineral sample over the $3800-2500 \mathrm{~cm}^{-1}$ spectral range is reported in Fig. 4a. Intense Raman bands are observed at 3478,3430 and $3379 \mathrm{~cm}^{-1}$ and are assigned to the stretching vibration of the hydroxyl units. The bands at 3080 and $3297 \mathrm{~cm}^{-1}$ are assigned to water stretching vibrations. The infrared spectrum over the $3800-2500 \mathrm{~cm}^{-1}$ spectral range is reported in Fig. 4b. The infrared spectrum is complex with overlapping bands observed. Band component analysis enables component bands to be resolved. Infrared bands are observed at 3532, 3470, 3387, 3241 and $3035 \mathrm{~cm}^{-1}$ are attributed to the $\mathrm{OH}$ stretching vibrations of the hydroxyl units, although the band at $3035 \mathrm{~cm}^{-1}$ may assigned to water stretching vibration. Breitinger et al. studied he mineral wardite. Although the structure of wardite is different to that of laueite, it is not unreasonable to make a comparison. Breitinger et al. [10] found infrared bands at $3520(\mathrm{vw}), 3545(\mathrm{~s}), 3585(\mathrm{sh})$ and $3613 \mathrm{~cm}^{-1}(\mathrm{~m})$. Breitinger et al. states that the $v(\mathrm{OH})$ modes in the two (a)

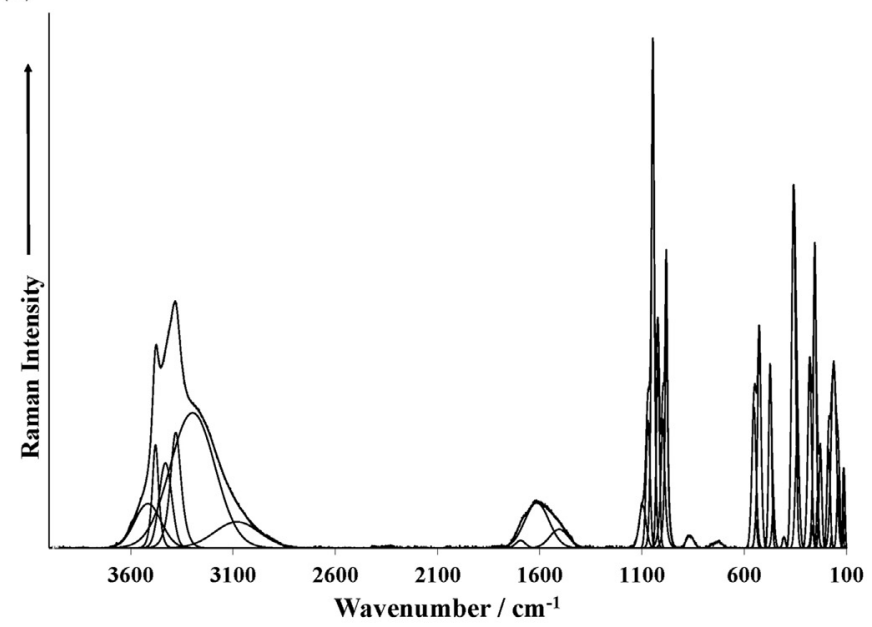

(b)

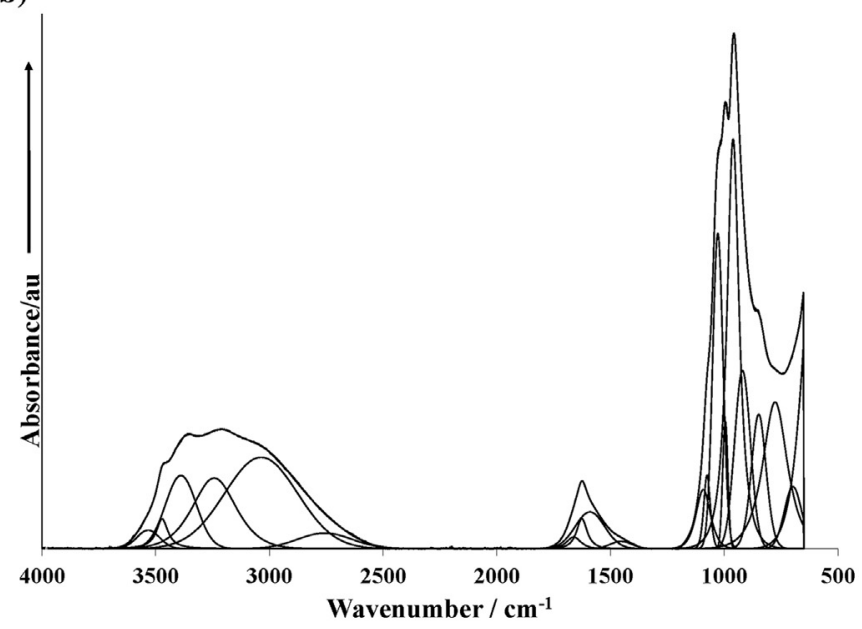

Fig. 3. (a) Raman spectrum of laueite over the $4000-100 \mathrm{~cm}^{-1}$ spectral range (b) infrared spectra of laueite over the $4000-500 \mathrm{~cm}^{-1}$ spectral range. 
Table 1

Vibrational spectroscopic data of laueite (lattice modes not listed).

\begin{tabular}{|c|c|c|}
\hline $\begin{array}{l}\text { Laueite } \\
\text { Raman }\end{array}$ & $\begin{array}{l}\text { Laueite } \\
\text { Infrared }\end{array}$ & Probable assignment \\
\hline 3515 & 3532 & $v_{(\mathrm{OH})}$ \\
\hline 3478 & 3470 & $v_{(\mathrm{OH})}$ \\
\hline 3430 & & $v_{\left(\mathrm{H}_{2} \mathrm{O}\right)}$ \\
\hline 3379 & 3387 & $v_{\left(\mathrm{H}_{2} \mathrm{O}\right)}$ \\
\hline 3297 & & $v_{\left(\mathrm{H}_{2} \mathrm{O}\right)}$ \\
\hline 3080 & 3035 & $v_{\left(\mathrm{H}_{2} \mathrm{O}\right)}$ \\
\hline 1692 & 1650 & $\delta_{\left(\mathrm{H}_{2} \mathrm{O}\right)}$ \\
\hline 1613 & 1624 & $\delta_{\left(\mathrm{H}_{2} \mathrm{O}\right)}$ \\
\hline 1096 & 1090 & $v_{3\left(\mathrm{PO}_{4}\right)}$ \\
\hline 1064 & 1074 & $v_{3\left(\mathrm{PO}_{4}\right)}$ \\
\hline 1045 & 1026 & $v_{3\left(\mathrm{PO}_{4}\right)}$ \\
\hline 1021 & 993 & $v_{1\left(\mathrm{PO}_{4}\right)}$ \\
\hline 997 & 959 & $v_{1\left(\mathrm{PO}_{4}\right)}$ \\
\hline 980 & 918 & $\gamma_{\left(\mathrm{H}_{2} \mathrm{O}\right)}$ \\
\hline \multirow[t]{2}{*}{864} & 864 & $\gamma_{\left(\mathrm{H}_{2} \mathrm{O}\right)}$ \\
\hline & 774 & $\gamma_{\left(\mathrm{H}_{2} \mathrm{O}\right)}$ \\
\hline 731 & 669 & $\gamma_{\left(\mathrm{H}_{2} \mathrm{O}\right)}$ \\
\hline 551 & & $\gamma_{4\left(\mathrm{PO}_{4}\right)}$ \\
\hline 542 & & $\gamma_{4\left(\mathrm{PO}_{4}\right)}$ \\
\hline 525 & & $\gamma_{4\left(\mathrm{PO}_{4}\right)}$ \\
\hline 472 & & $v_{2\left(\mathrm{PO}_{4}\right)}$ \\
\hline 456 & & $v_{2\left(\mathrm{PO}_{4}\right)}$ \\
\hline 404 & & $v_{2\left(\mathrm{PO}_{4}\right)}$ \\
\hline 357 & & $v_{1(\mathrm{FeO})}$ \\
\hline 335 & & $v_{1(\mathrm{FeO})}$ \\
\hline
\end{tabular}

independent pairs of symmetry-correlated $\mathrm{OH}$ groups classify as $2 a+2 b$; with the correlation splitting between $a$ and $b$ species depending on the distances in each of the pairs [10]. The $v(\mathrm{OH})$ region of IR spectra of laueite shows two sharp bands (3241 and $3387 \mathrm{~cm}^{-1}$ ) with two weak shoulders or satellites (3470 and $3532 \mathrm{~cm}^{-1}$ ). It is likely that the two sharp infrared bands are due to two independent and non-equivalent $\mathrm{OH}$ units. The two sharp shoulder bands may be attributed to the $\mathrm{Fe}-\mathrm{OH}-\mathrm{Fe}$ groups.

These bands at 3241 and $3387 \mathrm{~cm}^{-1}$ are assigned to water stretching vibrations. It is probable that some of the component bands are due to overtones and combination of the water bending and librational modes. The position of the water stretching vibration provides evidence for strong hydrogen bonding and that water is involved in different hydrogen bonding arrangements. The bands provide an indication that water is very strongly hydrogen bonded in the laueite structure. It is possible that the bands reflect the two isotypes of laueite as demonstrated by Moore [5].

The Raman spectrum of the laueite in the $1800-1300 \mathrm{~cm}^{-1}$ spectral range is illustrated in Fig. 5a. Two Raman bands are found at 1633 and $1692 \mathrm{~cm}^{-1}$. These bands are ascribed to water bending modes. The infrared spectrum of the laueite mineral sample over the $1800-1300 \mathrm{~cm}^{-1}$ spectral range is shown in Fig. 5b. Infrared bands are observed at 1589 and $1624 \mathrm{~cm}^{-1}$. The bands in this region result from correlation splitting as a result of the short distance and orientation of the $\mathrm{H}_{2} \mathrm{O}$ molecules.

The Raman spectrum of laueite in the $1250-650 \mathrm{~cm}^{-1}$ region is displayed in Fig. 6a. The spectrum is dominated by two intense bands at around 980 and $1045 \mathrm{~cm}^{-1}$. These two bands are assigned to the $v_{1} \mathrm{PO}_{4}{ }^{3-}$ symmetric stretching vibrations. The Raman spectrum of laueite from the RRUFF data base is provided in the supplementary information as Fig. S1. Two intense bands are observed at 976 and $1089 \mathrm{~cm}^{-1}$ with a shoulder band at $1003 \mathrm{~cm}^{-1}$. This spectrum differs from our spectrum as shown in Fig. 6a. Two intense bands are observed reflecting two non-equivalent phosphate units in the laueite structure, as was demonstrated by Moore [5]. Galy [11] first studied the polarized Raman spectra of the $\mathrm{H}_{2} \mathrm{PO}_{4}{ }^{-}$anion. Choi et al. reported the polarization spectra of
$\mathrm{NaH}_{2} \mathrm{PO}_{4}$ crystals. Casciani and Condrate [12] published spectra on brushite and monetite together with synthetic anhydrous monocalcium phosphate $\left(\mathrm{Ca}\left(\mathrm{H}_{2} \mathrm{PO}_{4}\right)_{2}\right)$, monocalcium dihydrogen phosphate hydrate $\left(\mathrm{Ca}\left(\mathrm{H}_{2} \mathrm{PO}_{4}\right)_{2} \cdot \mathrm{H}_{2} \mathrm{O}\right)$ and octacalcium phosphate $\left(\mathrm{Ca}_{8} \mathrm{H}_{2}\left(\mathrm{PO}_{4}\right)_{6} \cdot 5 \mathrm{H}_{2} \mathrm{O}\right)$. These authors determined band assignments for $\mathrm{Ca}\left(\mathrm{H}_{2} \mathrm{PO}_{4}\right)$ and reported bands at 1002 and $1011 \mathrm{~cm}^{-1}$ as $\mathrm{POH}$ and $\mathrm{PO}$ stretching vibrations, respectively. The two Raman bands at 1086 and $1167 \mathrm{~cm}^{-1}$ are attributed to both the HOP and PO antisymmetric stretching vibrations. Casciani and Condrate [12] tabulated Raman bands at 1132 and $1155 \mathrm{~cm}^{-1}$ and assigned these bands to $\mathrm{P}-\mathrm{O}$ symmetric and the $\mathrm{P}-\mathrm{O}$ antisymmetric stretching vibrations.

Breitinger et al. used FT-Raman to obtain their spectra of wardite and found overlapping Raman bands at 999 and $1033 \mathrm{~cm}^{-1}$ and assigned these bands to the $v_{1} \mathrm{PO}_{4}{ }^{3-}$ symmetric stretching and $v_{3} \mathrm{PO}_{4}{ }^{3-}$ antisymmetric stretching modes. The difference in the spectra between our work and that of Breitinger et al. may be attributed to the improved technology of the spectrometer with greater resolution. Other bands of lesser intensity are observed at $997,1021,1069$ and $1096 \mathrm{~cm}^{-1}$. These latter two bands are assigned to the $v_{3} \mathrm{PO}_{4}{ }^{3-}$ antisymmetric stretching vibrations. The first two bands are attributed to $v_{1} \mathrm{HOPO}_{3}{ }^{3-}$ stretching vibrations.

Breitinger et al. assigned the band at $999 \mathrm{~cm}^{-1}$ in the Raman spectrum of wardite to AlOH deformation modes. In this work the band at $997 \mathrm{~cm}^{-1}$ is quite sharp and well resolved. A group of low

(a)

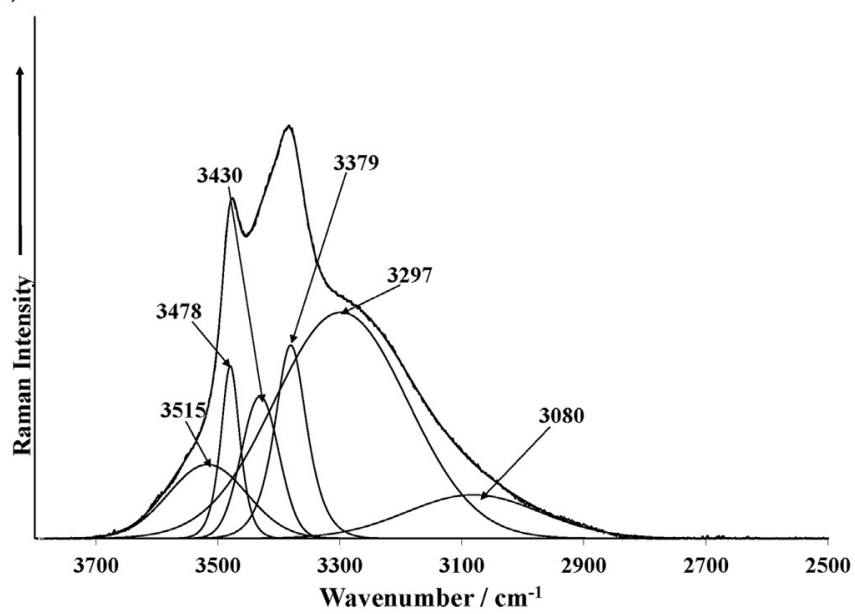

(b)

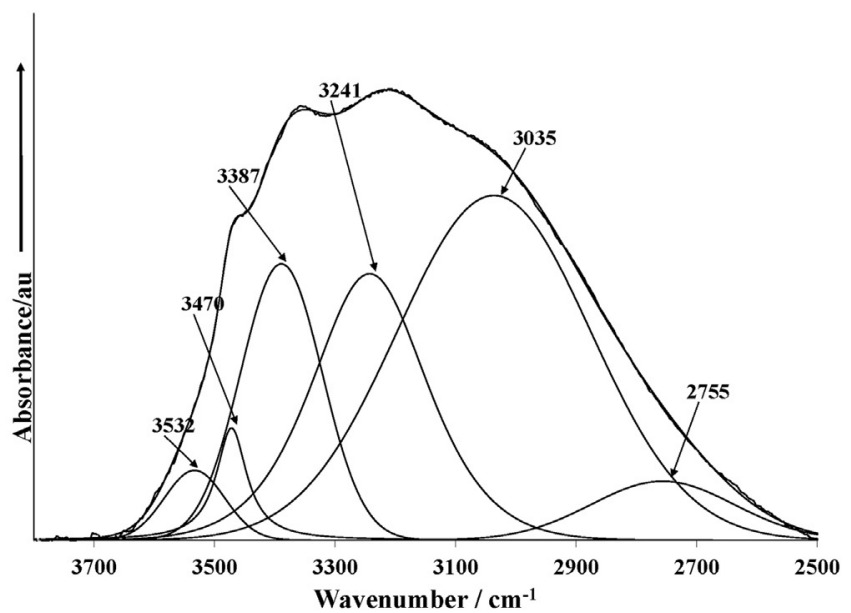

Fig. 4. (a) Raman spectrum of laueite over the $3800-2600 \mathrm{~cm}^{-1}$ spectral range (b) Infrared spectrum of laueite over the $3800-2500 \mathrm{~cm}^{-1}$ range. 
(a)

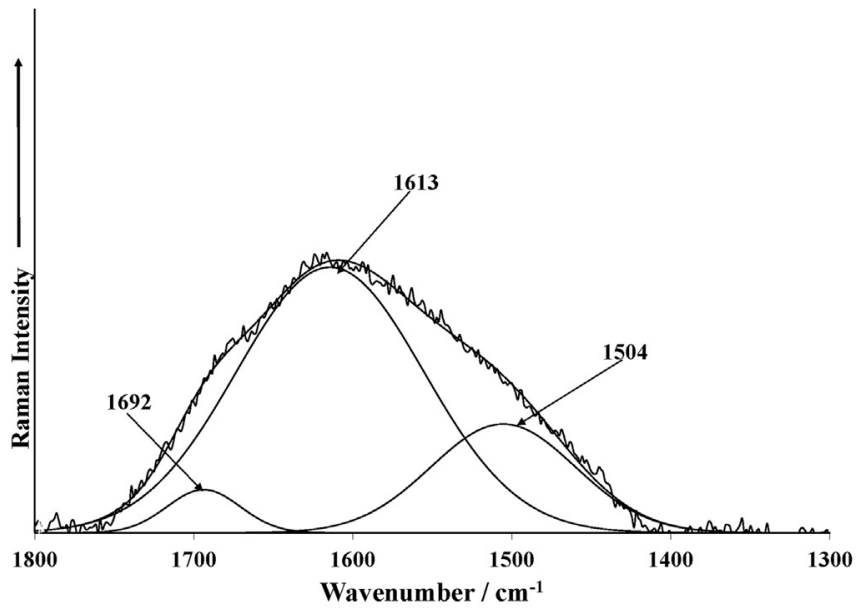

(b)

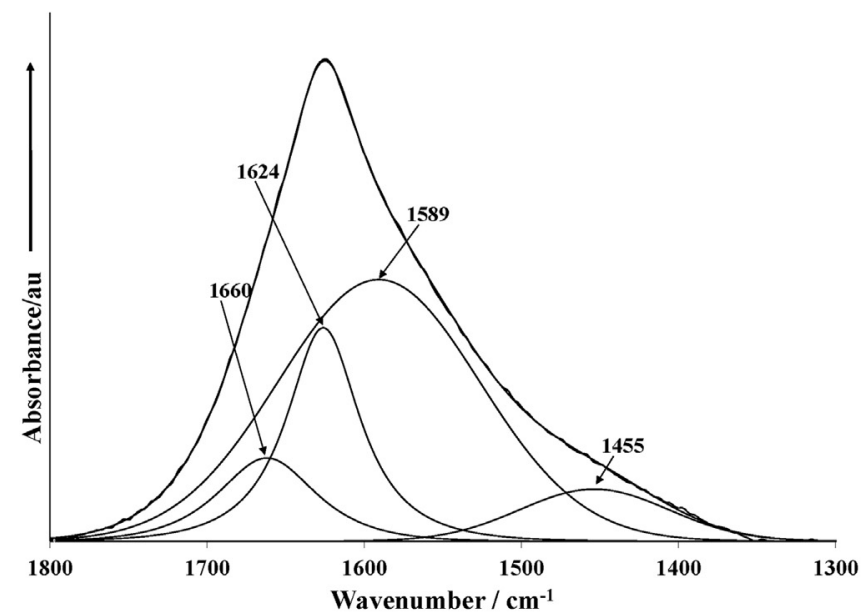

Fig. 5. (a) Raman and (b) infrared spectrum of laueite, both over the 1800$1300 \mathrm{~cm}^{-1}$ range.

intensity bands at 1069 and $1096 \mathrm{~cm}^{-1}$ and are assigned to the $\nu_{3}$ $\mathrm{PO}_{4}{ }^{3-}$ antisymmetric stretching modes. Breitinger et al. did not report any bands in these positions in the Raman spectrum of wardite. These workers reported infrared bands at 1058 (strong) with shoulders at 1129 and $1168 \mathrm{~cm}^{-1}$ and assigned these bands to $\delta \mathrm{Al}_{2} \mathrm{OH}$ deformation modes. A low intensity broad band at $864 \mathrm{~cm}^{-1}$ is assigned to a water librational mode. In the work of Breitinger et al., a broad low intensity band was found at around $800 \mathrm{~cm}^{-1}$ and was also attributed to water librational modes.

The infrared spectrum of laueite over the $1250-650 \mathrm{~cm}^{-1}$ spectral range is displayed in Fig. $6 \mathrm{~b}$. The infrared spectrum shows some similarity to that of the Raman spectrum. The infrared band at around $1026 \mathrm{~cm}^{-1}$ is attributed to the $v_{1} \mathrm{PO}_{4}{ }^{3-}$ symmetric stretching mode. The infrared bands at 1072 and $1090 \mathrm{~cm}^{-1}$ are attributed to the $v_{3} \mathrm{PO}_{4}{ }^{3-}$ antisymmetric stretching modes. The series of infrared bands at 774, 846 and $918 \mathrm{~cm}^{-1}$ are assigned to the water librational modes. Some of these bands may also be due to the $\delta \mathrm{Fe}_{2} \mathrm{OH}$ deformation modes, in harmony with the assignment of Breitinger et al. He and co-workers stated that the deceptively simple strong IR band centered at $1059 \mathrm{~cm}^{-1}$ for wardite contains at least four components of $v\left(\mathrm{PO}_{4}\right)$ generated by lifting of the originally threefold degeneracy of $v_{3}\left(\mathrm{PO}_{4}\right)$ and activation of $v_{1}\left(\mathrm{PO}_{4}\right)$ due to the general position of $\mathrm{PO}_{4}$ and again at least four components of the deformation modes $\delta\left(\mathrm{Al}_{2} \mathrm{OH}\right)$ involving the two pairs of the non-equivalent $\mathrm{OH}$ groups. In this (a)

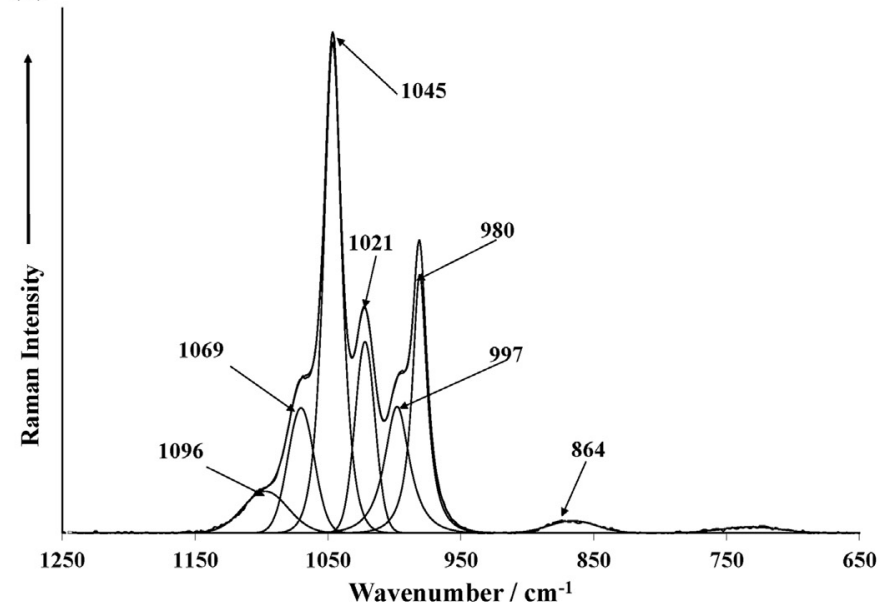

(b)

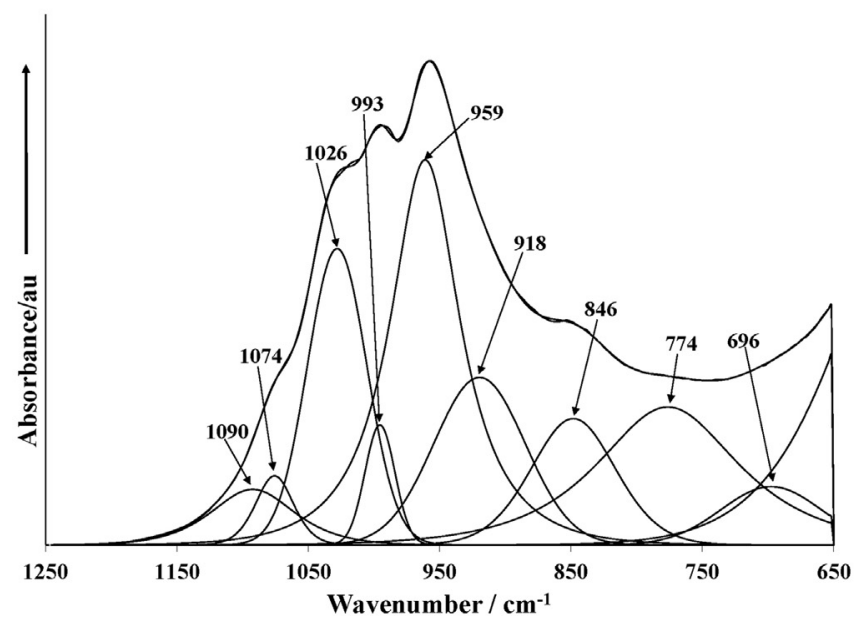

Fig. 6. (a) Raman and (b) infrared spectrum of laueite, both over the $1250-650 \mathrm{~cm}^{-1}$ range.

work we have obtained much greater resolution and these components are resolved into the component bands.

The Raman spectral region of the phosphate bending modes over the $800-100 \mathrm{~cm}^{-1}$ spectral range is reported in Fig. 7. Intense

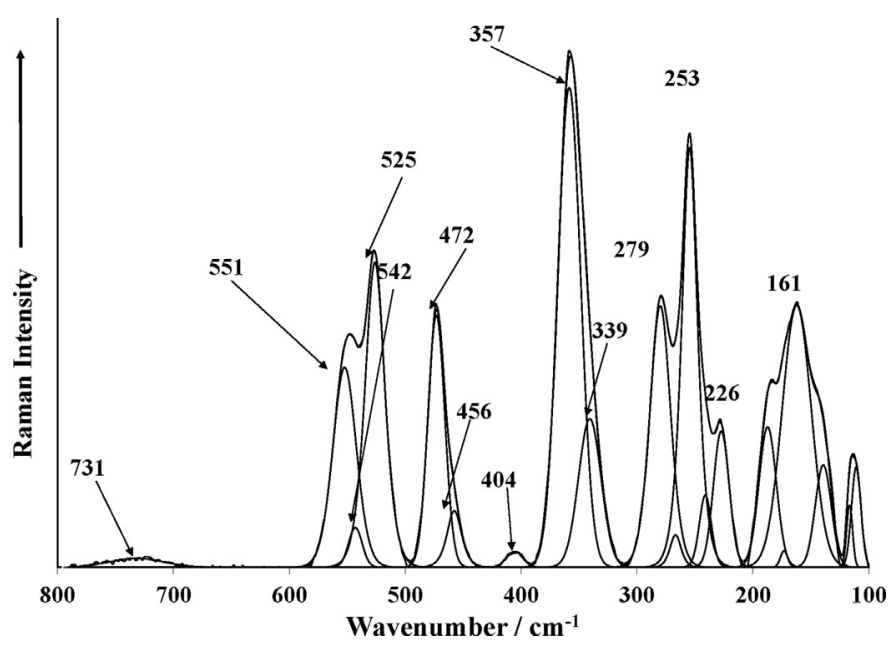

Fig. 7. Raman spectrum of laueite over the 800 to $100 \mathrm{~cm}^{-1}$ range. 
Raman bands are observed at 551, 542 and $525 \mathrm{~cm}^{-1}$ are assigned to the $v_{4}$ out of plane bending modes of the $\mathrm{PO}_{4}{ }^{3-}$ and $\mathrm{HOPO}_{3}{ }^{2-}$ units. In the RRUFF spectrum of laueite, Raman bands are found at 462, 516 and $577 \mathrm{~cm}^{-1}$.

The Raman band at $993 \mathrm{~cm}^{-1}$ is assigned to the $v_{1}$ symmetric stretching mode of the $\mathrm{POH}$ units, whereas the Raman band at $1009 \mathrm{~cm}^{-1}$ is assigned to the $v_{1}$ symmetric stretching mode of the $\mathrm{PO}_{4}{ }^{3-}$ units. Galy [11] first studied the polarized Raman spectra of the $\mathrm{H}_{2} \mathrm{PO}_{4}{ }^{-}$anion. Choi et al. reported the polarization spectra of $\mathrm{NaH}_{2} \mathrm{PO}_{4}$ crystals. Casciani and Condrate [12] published spectra on brushite and monetite together with synthetic anhydrous monocalcium phosphate $\left(\mathrm{Ca}\left(\mathrm{H}_{2} \mathrm{PO}_{4}\right)_{2}\right)$, monocalcium dihydrogen phosphate hydrate $\left(\mathrm{Ca}\left(\mathrm{H}_{2} \mathrm{PO}_{4}\right)_{2} \cdot \mathrm{H}_{2} \mathrm{O}\right)$ and octacalcium phosphate $\left(\mathrm{Ca}_{8} \mathrm{H}_{2}\left(\mathrm{PO}_{4}\right)_{6} \cdot 5 \mathrm{H}_{2} \mathrm{O}\right)$. These authors determined band assignments for $\mathrm{Ca}\left(\mathrm{H}_{2} \mathrm{PO}_{4}\right)$ and reported bands at 1002 and $1011 \mathrm{~cm}^{-1}$ as $\mathrm{POH}$ and $\mathrm{PO}$ stretching vibrations, respectively. The two Raman bands at 1086 and $1167 \mathrm{~cm}^{-1}$ are attributed to both the HOP and PO antisymmetric stretching vibrations. Casciani and Condrate [12] tabulated Raman bands at 1132 and $1155 \mathrm{~cm}^{-1}$ and assigned these bands to $\mathrm{P}-\mathrm{O}$ symmetric and the $\mathrm{P}-\mathrm{O}$ antisymmetric stretching vibrations.

Breitinger et al. assigned these bands at 551, 542 and $525 \mathrm{~cm}^{-1}$ to $v\left(\mathrm{Al}(\mathrm{O} / \mathrm{OH})_{6}\right)$ stretching vibrations. No phosphate bending modes in the work of Breitinger et al. were reported. The Raman spectrum of crystalline $\mathrm{NaH}_{2} \mathrm{PO}_{4}$ shows Raman bands at 526, 546 and $618 \mathrm{~cm}^{-1}$ (data obtained by the authors). A series of bands for laueite are observed at 472 and $456 \mathrm{~cm}^{-1}$. These bands are attributed to the $v_{2} \mathrm{PO}_{4}{ }^{3-}$ and $\mathrm{H}_{2} \mathrm{PO}_{4}$ bending modes. The Raman spectrum of $\mathrm{NaH}_{2} \mathrm{PO}_{4}$ shows Raman bands at 482 and $460 \mathrm{~cm}^{-1}$ and are attributed to the $\nu_{2} \mathrm{PO}_{4}{ }^{3-}$ bending modes. Raman bands at 317 , 446 and $515 \mathrm{~cm}^{-1}$ reported by Breitinger et al. were assigned to vibrational modes of the $\mathrm{AlO}_{6} / \mathrm{AlOH}_{6}$ units. Intense Raman bands at 357 and $339 \mathrm{~cm}^{-1}$ are assigned to the $\mathrm{FeO}$ and $\mathrm{MnO} v_{1}$ stretching vibrations. The low intensity Raman band at $731 \mathrm{~cm}^{-1}$ may be a second water librational mode. In the RRUFF spectrum, intense Raman bands are observed at 257 and $335 \mathrm{~cm}^{-1}$.

In the infrared spectrum (Fig. 6b) a series of bands are observed at 696,643 and $620 \mathrm{~cm}^{-1}$. These bands are attributed to the $v_{4}$ out of plane bending modes of the $\mathrm{PO}_{4}{ }^{3-}$ units. Breitinger et al. assigned bands in this region to $v\left(\mathrm{Al}(\mathrm{O} / \mathrm{OH})_{6}\right)$ stretching vibrations. In harmony with Breitinger et al. assignments, the infrared bands observed at 732,795 and $893 \mathrm{~cm}^{-1}$ are attributed to water librational modes. The Raman spectrum of laueite in the 300$100 \mathrm{~cm}^{-1}$ region is shown in Fig. 7. Intense Raman bands observed at $253 \mathrm{~cm}^{-1}$ for the laueite are related to the $\mathrm{O}-\mathrm{Fe}-\mathrm{O}$ skeletal stretching vibrations. Other bands in this part of the spectrum are noted at 226, 240, 265 and $279 \mathrm{~cm}^{-1}$. The intense band in all the spectra at $161 \mathrm{~cm}^{-1}$ is considered to be due to $\mathrm{H}-\mathrm{OH}$ hydrogen bonds. Other Raman bands are observed at 110, 115, 138, 172 and $186 \mathrm{~cm}^{-1}$. These bands are simply assigned to lattice vibrations.

\section{Conclusions}

Raman spectroscopy complemented with infrared spectroscopy has been used to study the molecular structure of mineral laueite from Brazil. The mineral specimen was also analysed using SEM with EDX technology. Chemical formula calculated on the basis of semi-quantitative chemical analysis of the studied sample can be expressed as $\left(\mathrm{Mn}^{2+}{ }_{0.85}, \mathrm{Fe}^{2+}{ }_{0.10} \mathrm{Mg}_{0.05}\right)_{\sum 1.00}\left(\mathrm{Fe}^{3}\right.$ $\left.{ }^{+}{ }_{1.90}, \mathrm{Al}_{0.10}\right)_{\sum 2.00}\left(\mathrm{PO}_{4}\right)_{2}(\mathrm{OH})_{2} \cdot 8 \mathrm{H}_{2} \mathrm{O}$.

The laueite structure is based on an infinite chains of vertexlinked oxygen octahedra, with $\mathrm{Fe}^{3+}$ occupying the octahedral centers, the chain oriented parallel to the $c$-axis and linked by $\mathrm{PO}_{4}$ groups. Two intense Raman bands observed at 980 and $1045 \mathrm{~cm}^{-1}$ are assigned to the $v_{1} \mathrm{PO}_{4}{ }^{3-}$ symmetric stretching mode. Intense Raman bands are observed at 525 and $551 \mathrm{~cm}^{-1}$ with a shoulder at $542 \mathrm{~cm}^{-1}$ are assigned to the $v_{4}$ out of plane bending modes of the $\mathrm{PO}_{4}{ }^{3-}$. The observation of multiple bands supports the concept of non-equivalent phosphate units in the structure. As a consequence at the molecular level non-equivalent phosphate units exist in the structure and multiple phosphate vibrational modes are observed.

\section{Acknowledgments}

The financial and infra-structure support of the Discipline of Nanotechnology and Molecular Science,Science and Engineering Faculty of the Queensland University of Technology, is gratefully acknowledged. The Australian Research Council (ARC) is thanked for funding the instrumentation. The authors would like to acknowledge the Center of Microscopy at the Universidade Federal de Minas Gerais (http://www.microscopia.ufmg.br) for providing the equipment and technical support for experiments involving electron microscopy. R. Scholz thanks to CNPq-Conselho Nacional de Desenvolvimento Científico e Tecnológico (grants Nos. 306287/ 2012-9 and 402852/2012-5) and PROPP/UFOP, project No. 03/2014.

\section{Appendix A. Supplementary data}

Supplementary data associated with this article can be found, in the online version, at http://dx.doi.org/10.1016/j.vibspec. 2015.12.001.

\section{References}

[1] W.H. Baur, Comparison of the crystal structures of pseudolaueite and laueite, Am. Mineral. 54 (1969) 1310-1321.

[2] P.J. Dunn, New occurrences for ushkovite and comments on laueite, Mineral. Rec. 16 (1985) 463-464.

[3] R.L. Frost, R. Scholz, A. Lopes, Y. Xi, Z.Z. Gobac, L.F.C. Horta, Raman and infrared spectroscopic characterization of the phosphate mineral paravauxite $\mathrm{Fe}^{2}$ ${ }^{+} \mathrm{Al}_{2}\left(\mathrm{PO}_{4}\right)_{2}(\mathrm{OH})_{2} \cdot 8 \mathrm{H}_{2} \mathrm{O}$, Spectrochim. Acta A 116 (2013) 491-496.

[4] R.L. Frost, Y. Xi, R. Scholz, F.M. Belotti, M. Candido Filho, The phosphate mineral sigloite $\mathrm{Fe}^{3+} \mathrm{Al}+\left(\mathrm{PO}_{4}\right)_{2}(\mathrm{OH})_{3} \cdot 7\left(\mathrm{H}_{2} \mathrm{O}\right)$, an exception to the paragenesis rule-a vibrational spectroscopic study, J. Mol. Struct. 1033 (2013) 258-264.

[5] P.B. Moore, The crystal structure of laueite, $\mathrm{Mn}^{2+} \mathrm{Fe}_{2}{ }^{3+}(\mathrm{OH})_{2}\left(\mathrm{PO}_{4}\right)_{2}\left(\mathrm{H}_{2} \mathrm{O}\right)$ 6. $2 \mathrm{H}_{2} \mathrm{O}$, Am. Mineral. 50 (1965) 1884-1892.

[6] P.B. Moore, Laueite, pseudolaueite, stewartite, and metavauxite. Combinatorial polymorphism, Neues Jb. Miner. Abh. 123 (1975) 148-159.

[7] P.B. Moore, T. Araki, Stewartite, $\mathrm{Mn}^{2+} \mathrm{Fe}_{2}{ }^{3+}(\mathrm{OH})_{2}\left(\mathrm{H}_{2} \mathrm{O}\right)_{6}\left[\mathrm{PO}_{4}\right] 2.2 \mathrm{H}_{2} \mathrm{O}$. Its atomic arrangement, Am. Mineral. 59 (1974) 1272-1276.

[8] M.A. Galliski, F.C. Hawthorne, Refinement of the crystal structure of ushkovite from Nevados de Palermo, Republica Argentina, Can. Mineral. 40 (2002) 929-937.

[9] P.B. Leavens, A.L. Rheingold, Crystal structures of gordonite, $\mathrm{MgAl}_{2}\left(\mathrm{PO}_{4}\right)_{2}(\mathrm{OH})_{2}\left(\mathrm{H}_{2} \mathrm{O}\right) 6.2 \mathrm{H}_{2} \mathrm{O}$, and its manganese analog, Neues Jb. Miner. Monat. (1988) 265-270.

[10] D.K. Breitinger, H.H. Belz, L. Hajba, V. Komlosi, J. Mink, G. Brehm, D. Colognesi, S.F. Parker, R.G. Schwab, Combined vibrational spectra of natural wardite, J. Mol. Struct. 706 (2004) 95-99.

[11] A. Galy, J. Phys. Radium 12 (1951) 827.

[12] F.S. Casciani, R.A. Condrate Sr., Proceedings International Congress on Phosphorus Compounds, 2nd edition, (1980) 175-190. 